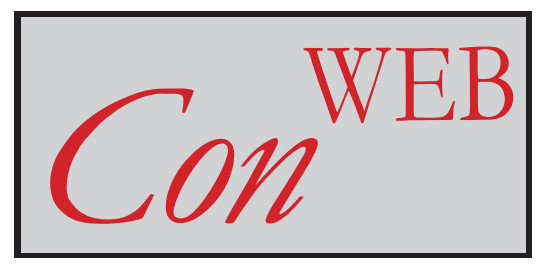

Webpapers on

Constitutionalism \& Governance beyond the State

Year 2003 | No 1

Improving EU Constitutional Politics? A Preliminary Assessment of the Convention

Carlos Closa, Departamento de Derecho Público, Universidad de Zaragoza

ISSN: 1756-7556

conWEB - webpapers on Constitutionalism and Governance beyond the State www.bath.ac.uk/esml/conWEB 


\title{
Improving EU Constitutional Politics? A Preliminary Assessment of the Convention $^{1}$
}

\author{
Carlos Closa, Departamento de Derecho Público, Universidad de Zaragoza \\ cclosa@posta.unizar.es
}

\section{ABSTRACT}

The Convention appears to many as both a confirmation of the thesis of the new institutionalism on the value of institutions for shaping the outcome of constitutional politics (the politics of creating EU fundamental rules) and a new model for democratic deliberative politics. From this second perspective, there is no doubt that it significantly improves EU constitutional politics but, when viewed against stringent procedural requirements defining the deliberation process, some defects appear. Representativity, procedures, the consensus rule and the Convention mandate provide standards to measure the criteria for assessing the democratic and legitimate character of the Convention.

\section{KEYWORDS: \\ Political Science Themes: constitutional change, democracy, legitimacy Treaty Reform: European Convention, Treaty reform Disciplinary Background: Political Science}

\section{Introduction}

A large and growing body of literature has consolidated the analysis of the EU political and legal order under the prism of 'constitutionalism'. By and large, legal and normative theory dominate this field with the effect of paying priority attention to issues such as the normative foundation of the EU or the relationship between different legal orders. Broadly, and with few exceptions, ${ }^{2}$ legal scholars have reflected on the legitimacy and democracy of existing order, as well as the prospects for future development whilst constitutional politics, i.e. the politics of creating and modifying EU fundamental and/or foundational rules and institutions, have been neglected. This paper proposes a reversion of the sequence underlying some analyses of EU legitimacy which have focussed overmuch on the legitimacy of formal outputs. Contrariwise, it argues that a deeper consideration of the specifically political aspects of the process of constitution-making is essential to the task of formulating normative conclusions. An interdisciplinary approach that brings the specifically political consideration of the process alongside legal-normative analysis will substantially benefit theorisation and/or explanations of EU constitutionalism.

EU constitutional politics (the process of creation and modification of foundational and fundamental rules and institutions) have so far proceeded through a mechanism, the Intergovernmental Conferences (IGCs), which ensures that national governments are able to maintain tight control over outcomes and negotiations. At all times, however, more or less 
detailed preparations precede the negotiation stage and a variety of ad hoc formats (committees, working groups, wise men reports, etc.) feed negotiators with preliminary studies, reports, drafts, etc. These informal but recurrent practices define what could be termed the preparatory stage of constitutional politics and, until the forthcoming 2004 IGC, they have been constrained within small and restricted groups of diplomats and/or selected politicians with little or no publicity as to their workings and scant feed-back from civil society.

The drafting of the Charter of Fundamental Rights of the European Union inaugurated a new procedure for the elaboration of constitutional rules, i.e. the Convention (whose very name was an act of self-assertion by releasing itself from its original designation as 'the body'), and its success prompted its adoption for the preparation of the forthcoming 2004 IGC. The Convention, followed by an IGC, splits the procedure of "constitutional" reform into two stages: a preparatory (deliberative) phase and a decision-making (negotiating) one and, in the eyes of the European leaders, this may resolve the dilemma of how to suffuse the Constitution-making exercise with legitimacy without relinquishing the "constitutive power" of national governments. Re-staging the preparatory phase within a Convention implies opening up EU constitutive politics to a deliberative process that, nevertheless, does not $a$ priori exclude the transactional dynamics of an IGC since preparatory outcomes do not necessarily bind upon "true" negotiators.

The significance for EU constitutional politics is dual. From the theoretical point of view, the Convention confirms the explanations of the new institutionalism concerning the mediating role of institutions and the impact of organisational choices on Treaty reform. In contrast with intergovernmentalist arguments, outcomes cannot be explained simply by focussing exclusively on governmental preferences and power. ${ }^{3}$ From the point of view of normative theory, the Convention represents a large improvement on previous preparatory mechanisms to an extent that may even escape the intentions of its creators. Authors praise the flexibility of its hybrid character, ${ }^{4}$ its deliberative quality ${ }^{5}$ and its value as an ideal forum that might become an excellent complement for the IGC model. ${ }^{6}$ With this addition, EU constitutional politics moves progressively towards a new combined constitutional method that includes three different phases: preparation, negotiation and ratification. In this way, the improvement of the democratic and legitimating credentials of EU constitutional politics moves to the first phase. The positive evaluation of this improvement cannot be overstated in view of the greater capability of the Convention to satisfy representative and deliberative requirements.

Nevertheless, the Convention also presents serious deficiencies owing to its "ambiguous" nature. Whilst it has assumed the preparatory groundwork for the reforms, a task until now usually carried through ad hoc committees, the Convention acts as a pseudoconstitutive assembly that has progressively moved towards the framing of a Constitution. From this second perspective, the Convention shows major shortcomings when judged against democratic standards of constitutional politics. Positioning herself within the theoretically informed inclusive and responsible constitutionalism deriving from Tully, Jo Shaw argues that not everything about the Convention will necessarily be a "good thing" (a perception that seems to be largely shared): its workings may be hi-jacked by dominant forces, its processes may be corrupted, etc. ${ }^{7}$ This paper reviews the Convention against the prospects of the final outcome being some sort of constitutional document. No doubt this prospective final outcome may make the Convention appear as a paradigm of representation and deliberation. 
Particularly, a much-heralded argument maintains that the outcome may be binding upon the IGC. Whilst this may resolve the shortcomings of past reform processes, the decisive issue of the citizens' final role remains open. Leaving aside the concrete procedures decided for its ratification, it might appear evident that a Constitutional outcome would enjoy greater legitimacy in the eyes of citizens if the drafting of the outcome respected stringent requirements of democracy and legitimacy.

The most appealing aspect of the Convention seems to be its deliberative character, which contrasts favourably with traditional IGCs. Deliberation has gained currency to describe the internal exchanges of some EU organs and bodies, such as the Committees, ${ }^{8}$ and it appears as an attractive model for democratising the EU. The deliberative perspective posits that opinions are shaped and tested in public debate and, further, that actors may change their preferences when faced with qualitatively better arguments. Hence, authority is founded on the 'reasonable' public discussion. ' But the mere existence of argument and reasoning does not mean that deliberation has naturally democratic legitimacy. The democratic and legitimate character of deliberation must satisfy previous criteria that this paper sets out to examine in the context of the Convention. Firstly, the composition of the Convention must be sensitive to the very notions of democratic and legitimate representation (section 2). Secondly, whilst the Convention appears a priori a suitable setting for guaranteeing a constitutional dialogue seeking agreement on principles, some of the procedural mechanisms framing deliberation described in section 3 induce reasonable doubt as to its deliberative quality. Thirdly, the method selected, consensus, is a pragmatic solution for reaching outcomes efficiently, but some democratic prerequisites seem to have been obviated (3). Finally the Convention mandate has been worked out in a constructivist fashion. By constantly referring to the objective of drafting a Constitution, this has become its obvious task without being explicitly so in the written mandate (4). Whilst this turn may finally assert its legitimacy and bind the IGC, no questions have been raised so far in connection with the previous mandate from the people and, obviously, no connection exists so far between the outcome and ratification by the citizens. In the first section, we review the reasons which explain the decision to organise a Convention on the Future of the EU.

\section{The transformation of EU "constitution-making" procedures}

The very tense and complex negotiations during the Nice summit had the immediate effect of provoking a widespread agreement on the limitations of the traditional method (the IGCs) for constitutional agreements. In particular, the summit cast doubt on the capacity of "top level" negotiators defending national interests and guided only by strategic considerations to settle the kind of framework issues that define the fundamental design of the EU. Several issues have limited the efficiency of the last two IGCs. ${ }^{10}$ The first are the increased divisions among Member States and the reduced or minimum influence of EU institutions, in particular the diminution of the Commission's mediating role. More decisively, the increasingly inflexible positions of national governments coincided with issues that do not produce win-win situations for all parties involved. This was the case, in particular, with the issues confronted at Nice (namely, the distribution of shares of power and votes).

Realistically, it is debatable whether these could be settled through the automatic application of a constitutional principle (such as proportionality) rather than as result of tough strategic bargaining and exchange between actors. In any case, these negotiations prompted a public and political reaction against the Treaty, which was decisive in persuading European leaders 
to relax a method (the IGC) that "fed the democratic deficit in the broadest sense of the word". 11

Perceptions of the limitations of constitution-making by merely aggregating actors' concrete choices and preferences coincided and contrasted with the smooth and solemn preparation and, subsequently, proclamation of the Charter of Fundamental Rights. This had the effect of translating a very positive perception of the outcome to the actual the method itself followed to draw up the Charter (despite its shortcomings and many criticisms). Notwithstanding some initial scepticism, and even criticism, the comparison between the IGC and the Convention turned to the latter's advantage ${ }^{12}$ and it appeared as an alternative to traditional diplomatic negotiations. ${ }^{13}$ National governments, in particular, have seemed to concede the vices of traditional IGCs, the agendas of which derive from unsettled issues plus those items that national governments themselves wish to include in order to reach an agreement. The possibility of veto grants a lot of room for national governments to pursue goals of their own. Against this background, outcomes do not follow a logic of deliberation but a logic of exchange and bargaining. Moreover, since parties seek to anticipate the future consequences of the constitutional provisions (for instance, the calculus of possible majorities following a given distribution of votes), the outcomes in each round of reform end up specifically tailored to suit the particular requirements of states and/or groups of states. This is not necessarily the best path or even a path to reach agreement on constitutional principles whose settlement might render ongoing constitutional negotiation unnecessary. In contrast, the Convention on the Charter appeared as an ideally deliberative setting able to reach agreement on issues of principle and EU member states (regardless of their size) and EU institutions coincided on this view.

The strategic considerations of the actors also helped drive the change of preference to the Convention model. Governments and leaders from small states resented their treatment by large states (particularly the French government) at Nice. In turn, they probably perceived the Convention as a prospective more egalitarian forum and their leaders reiterated demands (such as that of Paavo Lipponen ${ }^{14}$ or the Benelux Memorandum ${ }^{15}$ ) for a Convention. The Belgian Prime Minister, Verhofstadt, led the way during his tenure as President of the Council. ${ }^{16}$ In happy coincidence, the Convention format also suited national preferences of large states: some countries (e.g. France and the UK) wanted national parliaments to be involved into the process of constitutional reform. France had already suggested an antecedent of the Convention, the Assizes or Conference of Parliaments of the European Community (including the EP), convened to discuss next stages of Union in 1990, before the Maastricht IGC. ${ }^{17}$ Successive British governments have also supported the participation of national parliaments in EU politics.

A design that introduced safeguards and a priori guaranteed national governments' control $^{18}$ served to gain the acquiescence of reluctant governments (including the French, British, Danish and Swedish administrations) that regarded the Convention as potentially subversive. Thus, national representatives outnumber those from EU institutions; the very large size of the Convention may hinder the emergence of a strong self-organising capability and reinforces the role of the President; national governments retain the power to accept and/or reject the outcome and decide on its binding force; and they included a cooling-off period. Governments agreed because the process was unforeseeable, allowing them to hope they would be able to maximize their interests while retaining the opportunity to minimize costs at the subsequent IGC. ${ }^{19}$ 
EU institutions (EP and Commission) also favoured the Convention approach in the expectation that its working procedures amplify their ability to shape and influence outcomes. The EP campaigned in favour of the Convention more consistently and noisily than any other mainstream player. Borrowing the description by George Washington of the 1787 Convention of Philadelphia, the 1997 Tsatos and Méndez de Vigo report ${ }^{20}$ called for a Convention which can debate everything, can propose anything but can decide nothing. The EP reiterated its call in 2000 for the Constitutionalisation of the Treaties, ${ }^{21}$ and in its criticism of the Nice Treaty, it sanctioned the exhaustion of the intergovernmental mechanism of reform and repeated once again its proposal (this time on the precedent of the Charter one). ${ }^{22}$ Lastly, in November 2001, the EP approved a resolution on the constitutional process that detailed the profile of the Convention. ${ }^{23}$ The Commission showed its interest in this procedure more quietly but equally decisively. ${ }^{24}$ Both institutions perceive a comparative improvement of their role with respect to traditional IGC preparations since the institutional balance of current provisions (Art. 48) favours governmental actors. Both the EP and the Commission have appropriate material and human resources, and the deliberative ethos of the Convention provides a good playing field for their expertise on EU politics.

\section{Composition of the Convention: representation and legitimacy}

In their criticism of the democratic shortcomings of comitocracy, Eriksen and Fossum accurately criticise its lack of representativity. Democratic deliberation distinguishes itself from deliberation as a rational procedure for seeking agreement on the common good in it presupposes that the people directly or indirectly elect the deliberating subjects for that purpose. Following Sustein, these authors argue that representation may be seen as a precondition for political rationality as it secures institutional forums in which elected members of constituencies can peacefully and co-operatively seek alternatives and solve conflicts on a broader basis. ${ }^{25}$ Taking these preconditions into account, the capability and suitability of the Convention to legitimate outcomes derives largely from the quality of its members as legitimate representatives. Several criteria determine this quality: the selection procedure, the territorial levels represented, equality among parties, and the representativeness of conventioneers.

a. Selection procedure: Nomination of conventioneers avoided a specific electoral process. The European Council decided to include appointed representatives of European peoples from a range of bodies in addition to the representatives of the Heads of State and/or Government, and each agency chose its own selection procedures, which differed greatly in transparency. The combination of diplomatic and political actors that resulted helped to circumvent an exclusively negotiating setting and steer it towards a more deliberative one. Additionally, the very large size of the Convention (the 105 members doubled de facto because of the progressive incorporation of alternates as full members) enlarged the possible number of alliances and, in this way, provides a mechanism for circumventing deadlocks.

The appointment mechanism raises two difficulties. Firstly, despite formal personal autonomy (see below), Convention members depend on their nominating institutions and political shifts create changes that affect the stability of the composition (particularly in the case of national representatives). Secondly, in the absence of a "finalist" mandate (for instance, a constitutional mandate) from the people, reasonable doubts may be raised as to their legitimacy as representatives although this will depend very much on the kind of 
outcome that the Convention finally produces. In particular, a constitution-like outcome may face the objections of defenders of a theoretical view of "constituent power" on the grounds of the absence of any explicitly mandated body.

\section{b. Two level representation: national and European}

Composition mirrors the criteria followed in the former Convention. Two axes define the constituencies represented by Convention members: the territorial level providing representatives and the body represented. States and the EU are both represented at the first level, which implies a recognition of the dual source of legitimacy of the European Union. It is worth noting that for all the talk about distribution of competences among levels of governance and the defence of regions from any invasion of their competences by the Union, the third (or first) level of government has not been granted explicit representation despite the region's petitions. ${ }^{26}$ Regional presence is in fact indirect through the representatives of a Union institution (the Committee of Regions) and only with the status of observers. Whilst federal states (Austria, Germany and Belgium) wanted regions with legislative powers to designate the 3 regional observers, France (and, implicitly, the Spanish government) objected. As a concession to federal and quasi-federal states, regions and cities with legislative powers have nominated these observers.

Table 1 Composition by nationality

\begin{tabular}{|c|c|c|c|c|c|c|c|}
\hline & Presidency & $\begin{array}{l}\text { Govern. } \\
\text { Rep's }\end{array}$ & $\begin{array}{l}\text { National } \\
\text { MP's }\end{array}$ & MEP's & $\begin{array}{l}\text { European } \\
\text { Commission }\end{array}$ & Overall & Observers \\
\hline Member states & & & & & & & \\
\hline France & 1 & 1 (1) & $2 \quad(2)$ & $2 \quad(2)$ & 1 & (5) & 2 \\
\hline Italy & 1 & 1 (1) & $2 \quad(2)$ & $2 \quad(1)$ & (1) & (5) & 2 \\
\hline United Kingdom & & $1 \quad(1)$ & $2 \quad(2)$ & $3 \quad(2)$ & & (5) & \\
\hline Germany & & $1 \quad(1)$ & $2 \quad(2)$ & $3 \quad(1)$ & & (4) & 2 \\
\hline Portugal & & 1 (1) & $2 \quad(2)$ & $1 \quad(2)$ & 1 & (5) & 1 \\
\hline Belgium & 1 & 1 (1) & $2 \quad(2)$ & $1 \quad(0)$ & & (3) & 3 \\
\hline Austria & & 1 (1) & $2 \quad(2)$ & $1 \quad(2)$ & & (5) & 1 \\
\hline Denmark & & 1 (1) & $2 \quad(2)$ & $1 \quad(2)$ & & (5) & \\
\hline Spain & & 1 (1) & $2 \quad(2)$ & 1 (1) & & (4) & \\
\hline Netherlands & & 1 (1) & $2 \quad(2)$ & $1 \quad(0)$ & & (3) & \\
\hline Finland & & 1 (1) & $2 \quad(2)$ & $0 \quad(2)$ & & (5) & 2 \\
\hline Ireland & & 1 (1) & $2 \quad(2)$ & $0 \quad(1)$ & (1) & (5) & \\
\hline Greece & & $1 \quad(1)$ & $2 \quad(2)$ & $0 \quad(0)$ & & (3) & \\
\hline Luxembourg & & $1 \quad(1)$ & $2 \quad(2)$ & $0 \quad(0)$ & & (3) & \\
\hline Sweden & & $1 \quad(1)$ & $2 \quad(2)$ & $0 \quad(0)$ & & (3) & \\
\hline Subtotal & 3 & $15(15)$ & $30 \quad(30)$ & $16(16)$ & $(2)$ & $\begin{array}{ll}66 & (63)\end{array}$ & 13 \\
\hline $\begin{array}{l}\text { All candidate } \\
\text { countries }\end{array}$ & & 1 (1) & $2 \quad(2)$ & & & (3) & \\
\hline Subtotal & & 13 (13) & 26 (26) & & & $\begin{array}{ll}39 & (39)\end{array}$ & \\
\hline Total & 3 & $28 \quad 28$ & $56 \quad 56$ & 16 & 2 & $105 \quad 102$ & 13 \\
\hline
\end{tabular}

Source: Prepared by Ben Crum, CEPS 
The representation of states combines representatives of the executive and of the legislative. This specific shape adopts the compromise reached in the former Convention between those that wanted a purely parliamentary body (i.e. national and European MPs only) -France- and these who wanted the inclusion of representatives from national governments (UK and Germany), ${ }^{27}$ although the latter, strictly speaking, are personal representatives of the Heads of State or Government. ${ }^{28}$ Representatives of national parliaments secure a link with the negotiating and decision-making stage, whilst the direct participation of national parliaments provides for an input of legitimacy (given the consensus on this issue within the EU). The latter form the largest group within the Convention ${ }^{29}$ although it is obviously the least cohesive. Lacking the capability to act as a single body, a common culture or, personal assistants in Brussels, they are overburdened with commitments which, as was observed in the experience of the first convention, may make them prone to defection. ${ }^{30}$

Representatives of states outweigh representatives from EU institutions (which could be considered the representatives of the European people) 4 to 1. Even though this imbalance constructed a safeguard for national concerns, it does not translate automatically into a predominance of behaviour that strictly follows the logic of national interests. Rather, EU institutions benefit from the kind of "community skills" required for operating within the Convention setting. Members from EU institutions know each other and they are used to working within the trans-national environment on the same kind of issues. Direct personal knowledge and shared experience eases the creation of networks in which they may well be able to impose the prevalence of the "EU ethos" over a tight style of defence of national interests. Furthermore, some national government and national parliament representatives are former and/or current incumbents of EU posts. Thus, the representatives of the Spanish and Greek presidencies are or were MEPs and the representative of the Danish one is a former commissioner. This is fertile ground for the emergence of a significant comparative capacity on the part of both the Commission and the EP to shape proceedings and debates. They have expertise and a deep knowledge of EU affairs; they have material resources (background documents, staff, etc.); and both may more easily behave as a coherent group. ${ }^{31}$ The EP and the Commission debate the issues discussed in the Convention internally and these internal processes feed their representatives with skilful arguments and documents. Both have specific strategies with clear goals: the Commission aims at "promoting the Community method in a legitimate, transparent and dialectic confrontation". ${ }^{32}$ An additional leverage argument derives from their comparatively better presence in the Convention organs with 4 out of 12 members of the Presidium ${ }^{33}$ and the chair in 4 out of 10 Working Groups (which is particularly important given the power of the chairperson to set the agenda).

A number of factors reinforce the role of the EP. Firstly, its delegation had the advantage of continuity. Seven of the MEPs had been already members of the first convention (including the Chairman of the delegation, Méndez de Vigo who was to become a member of the Presidium in the second convention). Two other full members of the first convention became alternates and another alternate has repeated. In more practical terms, MEPs can devote more time and resources to the Convention than national representatives. A large number of preparatory documents back the MEPs and the EP regularly feeds the Convention with new material.

The Commission has consolidated its central role, both in terms of posts and the ability to shape debate starting from an initial marginal position at the first convention (in which it was initially to be included as a mere observer). The two Commissioners participate 
in the Presidium and both chaired working groups and contact groups. Commissioner Vitorino repeated as a Convention member and, no doubt, he has benefited from the previous experience. Whilst in the first convention the Commission acted as a kind of legal watchdog, ${ }^{34}$ it has now adopted a more proactive role submitting regular contributions, and Commissioners have taken an active part in debates. Additionally, the support it has lent to the Secretariat of the Convention (in the preparation of documents) has added to the Commission's influence. However, internal skirmishes (for instance, the unilateral presentation by Romano Prodi of a draft constitution and the angry reactions that followed) revealed a lack of cohesiveness in Commission views.

c. Representation of States: the principle of equality The representation of States has materialised around a basic principle of equality in representation both regarding their relative territorial size and population, and between current and would-be members (Turkey included). Also, national debates in applicant countries will be considered on an equal footing with those in current Member states.

However, the original procedural rules introduced some inequalities between the two categories. Thus, candidates cannot prevent any consensus that may emerge among current members. Given the uncertainty surrounding the future status of applicant countries, this could be presented as a fair safeguard although it also expresses some certain clubishness with current rules serving to distribute gains between current members and while shifting costs to would-be members. In any case, candidates do not necessarily share a priori common tastes on the future constitutional shape of the Union, leaving aside any mechanism attempting to sideline them. Since the issues at stake are basically matters of principle, though, gains and costs do not derive immediately from the fixing constitutional rules. Also, any final result that clearly discriminated between current and applicant members would represent a failure for the process.

The Convention redressed some other initial procedural and organisational inequalities. The Presidium accepted the candidates' request to have at least one representative on the Presidium, which implied a partial modification of the design of the Laeken Council. This representative has the status of invitee to the meetings. ${ }^{35}$ Pursuing equality of treatment, the Secretariat hired a national from each of the candidate countries. However, they did not obtain similar logistic support and the equal linguistic regime they had asked for (see below at 15)

\section{d. Representativeness: whom do conventioneers represent?}

The Convention model favours the emergence of political (i.e. ideological) filiations next to the diplomatic profile. Political parties were not part of the explicit pattern of representation chosen. Unavoidably, though, European parties have become very active and the ELRD, the PPE-ED and the PSE organized meetings with all their members in the convention (including commissioners, national MPs and MEPs). They have also submitted documents containing consensual proposals ${ }^{36}$ that may assist in the articulation of ideological debate. This possibility cannot be overemphasised. On the one hand, wide differences between national parties prevent the emergence of agreement on decisive issues, and proposals were vague and generic. On the other, leaders have shown a marked preference for alternative settings for party coordination. Thus, the PPE drafted a constitutional project ( $A$ Constitution for a strong Europe) outside the Convention scheme. The project, written by 
Wilfried Martens and Wolfgang Schäuble, was submitted congress of the PPE held in Lisbon in October 2002. Previously, Italian premier S. Berlusconi convoked seven demo-Christian prime ministers from EU member states to discuss the project. This initiative, according to Schäuble, followed the Spanish Prime Minister's active lobbying for a gathering of leaders once the Convention entered a decisive phase, in order to discuss some issues in petit committee (sic). ${ }^{37}$

A priori, party representation secures a wide and plural source of inputs, but the pattern within the Convention shows a leaning towards the two largest groups (see table 2 below). The two main cleavages in EU politics (Europeanist/Euroskeptics and right/left) are represented (although Giscard and the Euroskeptics themselves have noticed and complained respectively of their under-representation) together with a variety of other concerns.

Table 2 Composition by party affiliation

\begin{tabular}{|c|c|c|c|c|c|c|c|}
\hline & Presidency & Govern. Rep's & National MP's & & MEP's & $\begin{array}{c}\text { European } \\
\text { Commission }\end{array}$ & Total \\
\hline PES & 1 & $3(20 \%)$ & $13(43 \%)$ & 5 & $(31 \%)$ & 1 & $23(35 \%)$ \\
\hline EPP & 2 & $4(27 \%)$ & $11(37 \%)$ & 6 & $(38 \%)$ & 1 & $24(36 \%)$ \\
\hline ELDR & & $3(20 \%)$ & $4(13 \%)$ & 1 & $(6 \%)$ & & $8(12 \%)$ \\
\hline UEN & & $2(13 \%)$ & $1(3 \%)$ & 1 & $(6 \%)$ & & $4(6 \%)$ \\
\hline GRN & & $1(7 \%)$ & & 1 & $(6 \%)$ & & $2(3 \%)$ \\
\hline GUE/NGL & & & & 1 & $(6 \%)$ & & $1(2 \%)$ \\
\hline EDD & & & & 1 & $(6 \%)$ & & $1(2 \%)$ \\
\hline FPÖ & & & $1(3 \%)$ & & & & $1(2 \%)$ \\
\hline N/A / EPP * & & $1(7 \%)$ & & & & & $1(2 \%)$ \\
\hline N/A / PES * & & $1(7 \%)$ & & & & & $1(2 \%)$ \\
\hline Total & 3 & $15(100 \%)$ & $30(100 \%)$ & $\longdiv { 1 6 }$ & $(100 \%)$ & 2 & $66(100 \%)$ \\
\hline
\end{tabular}

* N/A means not formally attached, but party group of heads of state indicated. Source: Elaborated by Ben Crum, CEPS. Data as December,10 2002

In other respects, though, the Convention shows a remarkably low degree of representativeness. From the gender point of view, it has just 17 women out of 104 full members (16.35\%) improving marginally on the first convention (15\%), but this ratio worsens if directing positions are taken into account. Only two women belonged to the Presidium (out of 12 members) and just one of them chaired one of the working groups (Gisella Stuart). Noticing this situation, Giscard wrote: Elles compensent cette situation d'inferiorité numérique par la forte personalité de beaucoup d'entre elles (sic). ${ }^{38}$ Nor does the Convention accurately reflect the multicultural reality of many existing Member States with virtually no presence of minorities. It is impossible not to agree with Jo Shaw when she argues that these absences contradict the very constitutional objective of protecting minorities against the tyranny of the majority and ensuring that vulnerable groups receive enforceable protection. ${ }^{39}$

\section{Framing deliberation: Convention procedures}

The move from "preparatory body" towards a kind of "constitutional assembly" derives also from the qualitatively different procedures adopted by the Convention vis-à-vis traditional negotiations. The "assembly" profile leads almost naturally to deliberation. In this regard, Magnette, following Elster, has argued that a deliberative effect is visible in three elements: the "de-legitimation" of situated interests (i.e. representatives rarely speak on behalf 
of their respective bodies), the domination of a pragmatic discursive register and the absence of rigid and stable groups. ${ }^{40}$ This, no doubt, will provide the eventual outcome with a veneer of broader legitimacy.

However, democratically legitimate deliberation must be secured a priori by objective and explicit rules that frame discourse. ${ }^{41}$ The procedural features that frame discussion processes and the exchange of views, such as autonomy (of persons, rules and organs), the publicity and transparency of debates and the accessibility of demands from civil society define the democratic value of deliberation. Some authors have noticed that the mandate contained certain "safety features" (such as the election of the Chairman or the time limits imposed), providing protection against a bias towards a "strong" constitutional character. ${ }^{42}$ In fact, commentators recognise that deliberation has emerged thanks to the renegotiation of the rules imposed by mandate. ${ }^{43}$ The driving argument in this section is that rules securing values such as equal and free speech should not be a by-product of internal management of procedural rules.

a. Personal autonomy The precedent of the first Convention shows that autonomy is essential for vigorous deliberation to emerge, ${ }^{44}$ and, in fact, this is one of the clearest differences from classical negotiations with tightly mandated delegates. No official document defines the status of the members of the Convention vis-à$v i s$ their nominating institution and this vacuum allows divergence on the interpretation of the autonomy of members. Thus, Giscard disliked the term "representatives" and he favoured the very precise "conventioneers" (which lacks any connotation of "mandate"). ${ }^{45}$ He stimulated what has been called the 'Convention spirit', a loosely defined collaborative attitude aimed at finding common ground and avoiding a tight defence of national and/or institutional interests. Some of the procedural measures, for instance interventions upon request instead of representing groups and/or nationalities, or the seating pattern, clearly pointed in this direction. Not all actors shared this view, which favoured personal autonomy: the programme of the Spanish Presidency contained a veiled warning to convention members that they should act as true representatives of their institutions. ${ }^{46}$

Logically, the degree of autonomy differs between representatives from different institutions and/or bodies. Personal representatives may be expected to behave as "watchdogs" of national governments' interests and be subjected to instructions from national governments, even if they claim or it is argued that they enjoy autonomy. ${ }^{47}$ The description of the profiles of personal representatives (of Member States) reinforces this supposition (see table 2 below). Differently to the first Convention, governmental origin dominates with two vice-Presidents of Government, three ministers and three Secretaries of State or junior ministers, plus one top level official. Additionally, three lecturers, two MEPs and one lawyer are representatives of national governments of Member States. Even those countries (such as Germany or Spain), that initially nominated a "lighter" representative, quickly corrected by upgrading her standing (the Spanish representative became a Minister) or by substituting the representative by a Foreign Affairs Minister (Germany). Their high profile suggests an implicit recognition of the potential impact and importance of the Convention outcome. 
Closeness to government wishes may be fairly assumed, ${ }^{48}$ as may the representatives' role as gatekeepers of national governments' interests. To prevent any dilution of their visibility, the European Council recommended the an increased participation of representatives of Member States ${ }^{49}$ to President of the Convention, and some observers have noted the leading role of British and German representatives in seeking pragmatic solutions and finding common ground. ${ }^{50}$ The activity of government representatives secures a certain degree of control by national governments that may have the beneficial effect of securing a link with the decision-making stage at the 2004 IGC. In fact, the perception of the growing conditioning capacity of the Convention over the IGC has increased the pressure on those driving the agenda and making interim decisions to listen carefully to the dominant and more resonant interests within the Convention itself, as well as being aware of the dissonances that might appear between these interests and those which would be expected to drive the agenda of the IGC (notably, conflicts between large and small member states). ${ }^{51}$ On the other hand, their salience infuses proceedings with a "negotiation dynamic" that differs subtly from deliberative settings.

\section{Table 3 Professional backgrounds of Government Representatives}

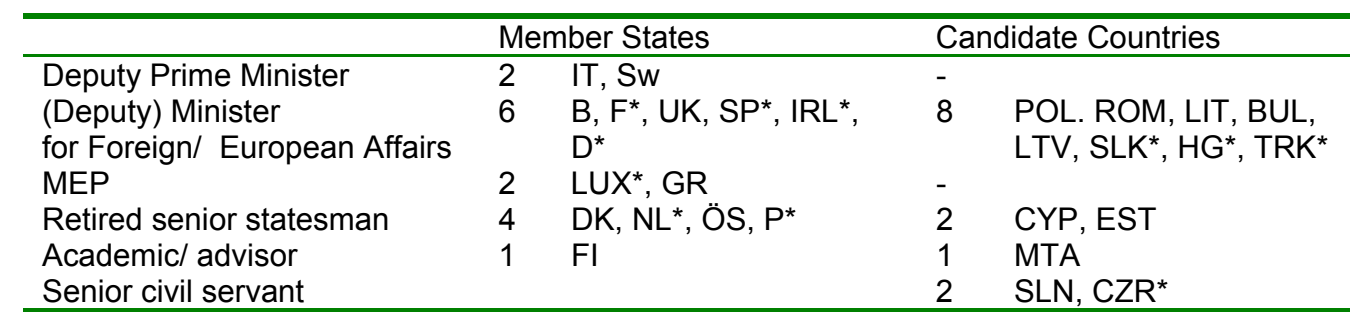

IRL* Roche replaced MacSharry

SP* de Palacio became minister of

$\mathrm{F}^{*}$ de Villepin replaced Moscovici

foreign affairs only later

P* Lopes replaced Joao de Vallera

$\mathrm{HG}^{*}$ Balázs replaced Martonyi

CZR* Kohout replaced Kavan

NL* de Vries replaced van Mierlo

TRK* Yakiş replaced M. Yilmaz

D* Fischer replaced Glotz

SLK* Korčok replaced Figel

Source: Prepared by Ben Crum, CEPS, Data as December 10, 2002

The absence of mandatory instructions from national parliaments delimitates the autonomy of national MPs. There has so far been no evidence of any different behaviour even when national parliaments have collectively taken a position or submitted documents to the Convention. ${ }^{52}$ But autonomy is somewhat limited by an unavoidable accountability and by pragmatic requirements. In most cases, representatives have been elected and, even though they are not bound by mandatory instructions, they have close ties and report to their original institutions (most commonly, to specialized EU Committees). For instance, in the UK, apart from reporting and giving regular evidence, a special committee (made up of members of both chambers) has been set up for the duration of the Convention. Different parliamentary traditions and prevailing attitudes to the EU also define different levels of control and direction and, obviously, a tight control from national chambers implies a reduction of the 
margin for autonomous deliberation. But, on the other hand, close connection with national parliaments is highly advisable since these very organs will have to ratify the outcome.

b. Organizational autonomy. The autonomy of Convention organs (which structure and lead work) presents a mix balance. Even though the Laeken mandate granted organisational autonomy, the Convention has used it to create and regulate secondary organs (mainly working groups). The definition and appointment of the main organs of the Convention (President and Presidium) by an outside authority (i.e. the European Council) implies a loss of organisational autonomy that affects the representativeness of these organs. In parallel, their design simultaneously combines organizational and "political" functions which are separated in other deliberative assemblies (for instance, Parliaments).

President. The President of any deliberative democratic institution (as is the case, for instance, with parliaments) has significant procedural mechanisms available to establish his/her position of primacy. Additionally, the role requires an intangible resource, autorictas, the recognition of a certain preeminence. Leaving aside charismatic leadership, this autorictas derives from the election procedure: deliberative bodies normally select their Chairperson. This probably explains the role of Herzog in the first convention (a strong and respected personality even though he was not a prominent political figure across Europe in the same way as Giscard is). Nevertheless, the European Council at Laeken broke with precedent and elected the President and Vicepresidents for the 2002 Convention. This election, surrounded as it was by the traditional struggle over EU posts, did not benefit the salience of the President. $^{53}$

The formal exclusive prerogatives of the President are rather limited but that does not mean he lacks influence. Thus, he inspired a number of decisions that reinforced the coherence of the Convention: decisions on phasing, the sitting in alphabetical order and his resistance to introducing voting. Some authors grant Giscard a positive role in shaping the Convention: his conception and choices have effectively turned the Convention into a forum not only for deliberation, but also one that aims to find cross-party and interinstitutional compromise. ${ }^{54}$ However, he has also been able to exercise influence through the skilful utilisation of his position, which may in the end amount to subtly converting his own agenda into the Convention agenda. In a number of cases, he has done so by merely appealing either to his own judgement or to opinion, or behaving as an omniscient interpreter of public opinion and public wishes. For instance, he wrote, Il me semble, à titre personnel, que la legitimité démocratique de l'Union ne sera pas reconnue comme complete par les citoyens aussi longtemps qu'il n'existera pas un lieu de recontre organique entre les deux legitimités de l'Union: les legitimités nationals et la legitimité européenne. C'est pouruqoi je proposerai à la Convention de réflechir à l'instauration d'un Congrès des peoples d'Europe. ${ }^{55}$ This behaviour can be perceived in Giscard's steering of the Convention 
debates, in his relationship with the European Council (reporting) and in his public presentation of his personal (rather than institutional) opinion. This host of activities made some members of the Convention fear that Giscard intended to dictate the key elements of the final document, working closely with the Secretariat $(\ldots)$ and in close consultation with key national governments. ${ }^{56}$

- Steering the debates. Giscard presented himself as a 'neutral' actor. But written records illustrate a number of occasions on which he used his summarizing role to rescue his favourite option and bring it into the foreground regardless of the support that it attracted in the debate. Summaries of plenary session recorded a number of cases in which this happened. For instance, in the debates on the third pillar, the summary recorded "a large majority questioned whether that division (in pillars) was justified and argued in favour of full 'communitarisation' of current third pillar issues". ${ }^{57}$ But in his summary of this debate, Giscard suggested "a pragmatic approach (on the issue of the division in pillars), examining without any preconceptions (sic) which actions could be best dealt with by which procedures" ${ }^{58}$ A second example of the same behaviour refers to the debate on national parliaments. The written summary records a large majority of Convention members doubted the usefulness of creating a new institution that would represent national parliaments only ${ }^{59}$ However, his closing summary recorded the following: "the Chairman found that statements by members of the convention were aimed at making improvements to the current system. The question, however, as far as he was concerned, was whether citizens were perhaps not expecting more from the Convention's work; he therefore asked the Chairman of the working group on national parliaments not to rule out an innovative initiative. $^{60}$

- Reporting. The Laeken Declaration imposed the duty of reporting to the European Council on the President. The perception of this function from the European Council emphasises a certain "controlling" dimension. The view of Spanish Prime Minister Aznar acting as President of the Council underlined that "a synergetic relationship with the Council was essential since this would be the institution that will adopt the definitive decisions on the reform of the Treaties". ${ }^{61}$ Giscard has skilfully exploited his duty to report as an instrument for further voicing his views. Thus, Giscard did not submit his report to the Convention before attending the Seville European Council, although he circulated a written copy when he informed the Convention afterwards. ${ }^{62}$ His report was received with some criticism. Belgian MP Di Rupo argued that the report translated the President's personal view and hence, they (the Convention) could not feel obliged by it. ${ }^{63}$

- Publicising his opinion. The ill-defined accountability and representative role of Giscard with respect to the Convention has allowed him so far to air different or even contradictory opinions to those of the body he chairs. Landmarks of his 'independent' stance are his July 2002 Le Monde article, ${ }^{64}$ his speech at the College of Europe at Bruges on 2 October $2002^{65}$ and an interview with the Financial Times on 7 October 2002. In all these, he put forward either themes not dealt with by the Convention and/or different views: 
he rejected federalism, which prompted a sharp reaction from the numerous federalist sympathisers within the Convention; he proposed (seemingly out of the blue) the discussion of new names for the EU (European Community, European Union, United Europe, United States of Europe); and he twice repeated his proposal to create a Congress of the Peoples of Europe gathering both MEPs and national parliamentarians with the task of examining the "state of the Union'. ${ }^{66}$ Some Convention members thought that Giscard failed to play the part of honest broker and instead 'hijacked' the Convention's will, imposing his own ideas. A dominant perception among commentators is that, in any case, Giscard will push for a relevant result (even a Constitution), since he seems eager to seize the historical moment to become the "father" of the Constitution of the EU. ${ }^{67}$

Presidium. Following the pragmatic experience of the first Convention, the European Council invested the Presidium with a wide range of functions that makes it the most important organ of the Convention. ${ }^{68}$ The implicit functions that it has assumed further reinforced its initial strong position (given by the explicit functions granted by the European Council). In a tight summary, the Presidium led proceedings and provided a working basis for it. Thus, it drafted the agenda, channelled contacts with civil society and supervised the Working Groups. Observers have noticed, after the first months of the Convention's work, that the Presidium did not develop an identity as a political team or a cohesive group and, according to one observer, some tensions arose between its members and the President. ${ }^{69}$ This relatively loose structure is reinforced in the sense that neither vice-president considers himself as subordinate to Giscard and both have substantive tasks within the Convention.

The working groups. Whilst the first Convention did not operate working groups, the current one created an initial six in May and a further four in September, as well as one (Social Europe) in November 2002. Any member or alternate could participate in any of group, although the Presidium took this decision in order to respect equilibriums. Again, composition does not follow any kind of a priori representative criteria and/or result from election.

Lacking a previous definition of their function, the Presidium and Giscard have attempted to define a low political profile for them. Above all, they should avoid fragmentation. In Giscard's words, care should be taken to avoid (the Convention) being split up as a result of the creation of working groups. ${ }^{70}$ Because of this, he insisted, the Convention departs from the model of committee specialization characterising Parliaments. ${ }^{71}$ Working Groups have a constrained agenda: they examine particular issues already identified in the course of convention debates following specific mandates given by the Convention, which converted the issues to be clarified into questions. They also have a reporting task, which is to submit possible options. No doubt, they provoked deeper discussions since they are not subject to the strict limitations of plenary sessions. Groups would also benefit from tighter contacts and more permanent presence, but they were subject to strict time deadlines on their 
work, a limitation which restricted their ability to innovate and has forced them to concentrate on their agendas.

c. Procedural autonomy. Although the Declaration of Laeken determined the main organizational traits of the Convention, this could adopt its own rules of procedure. ${ }^{72}$ In this way, the Convention increased its autonomy vis-à-vis EU institutions and national governments. Procedural rules redressed certain lacunae and imbalances in the basic design of the Convention, such as the presence of a representative of applicant countries in the Presidium. More decisively, the Convention has re-defined its own mandate (see section 4 below), its own agenda and the duration of its work until June 2003 (disregarding the original injunction to end within a year). Ending by 2003 sought to establish a "cooling-off" period before starting the IGC, which would allow it to distance itself from the results of the Convention. ${ }^{73}$

d. Transparency. Two different mechanisms, publicity and linguistic accessibility, upheld this key principle for good governance. As for the first, the open meetings and debates of the Convention are a great improvement on the obscurity of traditional IGCs. Documents and deliberations are public and published on-line (essential in the first convention to increase the influence of NGOs, for instance) but this refers specifically to documents from the main body, the plenary. Transparency does not reach all the workings of the leading organs of the Convention. Presidium workings, proceedings and debates are neither public nor published. As for the working groups, their documents are also submitted for Internet accessibility, but every chairperson decided whether to hold public sessions or not. ${ }^{74}$

The linguistic regime provided for translation into all eleven languages. The linguistic regime for applicant countries, as designed by the Laeken Council, initially lacked this virtue. Candidate countries asked for similar treatment to current members (an issue which was not decided by the Laeken Declaration). The Presidium opined that this was a reasonable petition and it justified its opinion arguing that it was necessary to keep public opinion in these countries informed. Initially, this concerned the availability of "summary notes" from plenary sessions (translation provided by national representations). ${ }^{75}$ Then, the Presidium accepted that the representatives from these countries could address the plenary sessions in their own languages. ${ }^{76}$ Forum contributions could be submitted in any language and were published in all languages submitted.

e. Openness: the role of civil society. One of the most heralded attributes of the first Convention was its closeness to society in comparison to any IGC and, hence, a more accurate reflection of it. ${ }^{77}$ The participation of civil society strengthened the legitimacy of the procedure and the outcome. Drawing inspiration from that experience, the role accorded to civil society organizations and the procedures used greatly improve on the former convention, whilst the numbers of these involved have also risen significantly. There are two different facets to the legitimising role of civil society and organizations. One is passive, meaning that the organizations and groups act as receivers of information and as a "public" for the Convention. Whilst this secures publicity for proceedings, it does not necessarily imply capacity to influence 
them. This is precisely the second, i.e. active role, which makes civil society and groups into providers of inputs. Overall, it seems that the role of civil society fits mostly in the passive dimension.

An unavoidable "instrumental" character conditioned the relationship between the Convention and civil society and this does not fit well with the fluid nature of the latter. The Convention privileged the Forum, a structured network of organizations that will be regularly informed of the proceedings of the Convention. The only requirement for participation was the submission of a written contribution and this opened the door for significant participation (207 groups and organisations). ${ }^{78}$ Even so, the Forum presents problems of representativeness. There is no Portuguese group, very few groups from applicant countries and some social concerns (such as immigrants or asylum seekers) are not represented.

A second instrumental dimension refers to the discretionary capability of the Convention/Presidium to decide when and with whom to celebrate hearings following the criteria of utility for specific aspects of the proceedings. For this, they could select the prospective participants around "chosen" topics. Groups themselves may encounter difficulties providing substantial inputs: the wider and less precise agenda of the exercise and its political nature may imply that, a priori, groups are not easily able to identify direct interests at stake in the issues discussed. This may lead towards a certain loss of focus and perhaps towards a more reactive attitude. The plenary session with civil society proved disappointing in the opinion of some commentators who sharply criticised the selection criteria: a gathering of the Commission's payroll of funded lobby groups, the usual suspects saying the usual things. ${ }^{79}$ Although a significant number of persons and associations participated in this plenary session, participants complained about the lack of physical space and the very reduced time for presentation (5 minutes). As the same commentator has noted, the Convention's consultative effort is demand-led. Supply is plentiful but the resources and time to digest the enthusiastic flood of materials and ideas (in some cases, described as carpet selling) are painfully slight The Convention is open to advice but is not in the mood for distracting participation. ${ }^{80}$

The Presidium and the Convention have also encouraged self-organisation on the pattern observed in the first convention. The Presidium document that maps out the modalities for hearing and/or consulting civil society, ${ }^{81}$ argues that the efficacy of contacts will depend on the capability of civil society to organize itself into contact groups. This has the effect of favouring the most active groups (rather than those with a higher profile) and stimulating informal consultation (understood as full access to all Convention members). As Jo Shaw has observed, there remains a gap between the types of move that the Convention has made towards receptiveness, including the Forum, listening to civil society and the Youth Convention, and the creation of a genuine public sphere. $^{82}$

However positive the appeal to civil society, the exercise should not confuse or avoid the consideration of the citizenry. Consultations broaden the scope of these consulted but, as was noticed in relation to the first Convention, European citizens did not take part in the exercise in any great numbers. ${ }^{83}$ Equally, the prospects for this second Convention do not look bright from this particular angle. Eurobarometre polls show underlying support for the idea of a European Constitution (see Table 4 below). 
But this does not translate into an equally positive perception of the Convention itself: only a minority has heard of it, and it remains the least known of all the EU institutions (apart from the Committee of Regions). Similarly, the perception of its importance ranked the second lowest and far distant from the importance granted to other EU institutions. More worryingly, it was the least trusted of EU institutions. This, of course, may raise serious questions for the legitimacy of the Convention and its outcome, which, theoretically at least, assumes a wider receptiveness and a pluralistic source of inputs. In practice, the figures quoted mean that any output from the Convention is from the outset likely to face similarly severe prejudice from public opinion as earlier reforms. Underlying this is the lack of a "communicative strategy" by the Convention, which translates into the usual inability to connect with the average citizen. Thus, a new "attention" deficit parallels the "democratic" deficit: neither the mainstream media nor the citizen-in-the-street appears engaged by the Convention, or, indeed, the broader questions on the future of Europe. ${ }^{84}$

Table 4

\begin{tabular}{|l|c|c|c|c|c|c||}
\hline \multicolumn{7}{|c||}{ Eurobarometer Standard Polls } \\
\hline \multicolumn{7}{|c||}{ Results in percentages } \\
\hline & $\begin{array}{c}\text { Autumn 2002 } \\
\text { (EB 58) }\end{array}$ & $\begin{array}{c}\text { Spring 2002 } \\
\text { (EB 57) }\end{array}$ & $\begin{array}{c}\text { Autumn 2001 } \\
\text { (EB 56) }\end{array}$ \\
\cline { 2 - 8 } & Yes & No & Yes & No & Yes & No \\
\hline Support for a European Constitution & 65 & 9 & 63 & 10 & 67 & 10 \\
Knowledge of the Convention & 28 & & 28 & & & \\
Importance of the Convention & 39 & 14 & 35 & 16 & & \\
Trust in the Convention & 29 & 21 & 25 & 22 & & \\
\hline
\end{tabular}

Source: Drawn from Eurobarometer data

\section{The objective of deliberation: consensus}

The mandate from the European Council establishes the possibility of tabling final recommendations for the IGC if backed by consensus. Since the Convention eagerly pursued the objective of making its outcome as binding as possible, it engaged from the very beginning in the search for consensus. What does consensus exactly means? It could be understood as a basic agreement largely shared by most participants. A broadly shared agreement implies the concurrence of most players and signifies that the outcome satisfies a large majority of them. As an example, the Spanish transition to democracy and its main landmark, the 1978 Constitution, is broadly defined as consensual. What lends it the characteristic of consensus is the attention paid to most concerns of different representative groups that share basic and fundamental principles. In this sense, consensus does not rule out voting (and in fact, the consensual constitution of Spain was voted), but it implies that large supporting majorities are sought around fundamental agreements.

The EU Convention has not defined what is explicitly meant by consensus, but it seems that is interpreted first and foremost as the absence of formal voting. In the first convention, it was understood that the level of consensus required lay between unanimity and a majority. ${ }^{85}$ But in the absence of voting to measure how many support an option, the search 
for consensus involves a simultaneous exercise of defining the substantial components on which coincident views appear and assessing the existence of a large supporting majority without counting. The advantage of this procedure is that it may stimulate deliberation and dialogue. Deprived from the equalising mechanism of voting, opinions have to be aired to substantiate opposition or support. Also, persuasion is essential to convince participants to maintain a certain opinion. Some procedural devices introduced in the Convention debates, such as "blue cards" (i.e. non scheduled interventions to question speakers) and "green cards" (i.e. speakers' replies to the former) no doubt produce a certain dialogue. The combined effect of arguing, plus the absence of formal voting favours a certain "endogenization" of preferences: at the risk of exclusion, preference formation becomes shaped by the more cohesive environment in which it occurs. ${ }^{86}$

However, the centrality of speech provokes inequalities. In practical terms, time limits introduced by the Presidium limited the number of speakers that could take the floor on each topic. ${ }^{87}$ The summaries of debates record agreement by using expressions such as "a very large majority", "most speakers", "large majority", "majority", "many speakers", "a number of speakers", "several", "certain" and "some". The unit for counting is not members but speakers, i.e. those that make their opinion heard. This introduces a basic inequality: since speakers in general represent themselves (in contrast to representative assemblies), consensus reflects the coincidence of speakers (and not conventioneers) on the same or a very similar point of view. Because of this, observers argue that voting gives equal power to each member of the convention, and hence there is a recommendation in favour of using voting additionally to consensus, particularly in more restricted groups. ${ }^{88}$

A second difficulty with the method followed derives from the fact that, deprived of voting, the key procedural function is the identification and integration of coincidences and options. The method followed by the convention for these functions of integrating and identifying has been a "to and fro" procedure. Debate starts with an issue from a paper submitted by the Presidium, stock is taken of opinions and summarized and, again debate starts from this new point. Papers (both initial but, in particular, summary) are essential elements for this exercise. An example of how this method works is the debate on the distribution of competences and the functions of the Union. Debate started on framing documents prepared by the Secretariat ${ }^{89}$ which were discussed in plenary session. ${ }^{90}$ Taking stock of the debate, the Secretariat redrafted the paper ${ }^{91}$ and submitted it for a new debate in plenary session. ${ }^{92}$ At the end of this, the Chairman was able to record consensus on certain themes, for instance, a prevailing view that, on the whole, the present system of allocation of competences was right.

The procedure strengthens the drafters of supporting documents (Secretariat and Presidium), the more so since the overload of contributions from convention members and other origins reduces the capability of individual conventioneers to follow up the documentation (from mere time pressures to capacity to follow up all contours of debate), or even to read it. This forces conventioneers to focus on the "backbone" papers (summaries and background papers). Giscard has underlined that the task of the Conference is not a discussion of contributions (however detailed they are) but to reach a global position. Above all, the procedure strengthens the Chairman, who has a decisive role in identifying and integrating the opinions of speakers. And he declares the existence of consensus from the apparent coincidence of speakers. Since he cannot be outvoted, he has an excellent opportunity to "model" the substantial agreement, as has already been mentioned above. As in the first 
Convention, the absence of voting (rather than the search for consensus) has some adverse effects on the openness of the exercise and it may give advantage to certain players.

\section{The Convention mandate}

The Convention has evolved from an open (agenda) and un-specific (outcome) mandate towards a self-mandate of a constitutional kind. By-passing the more or less explicit safeguards introduced through its design as a preparatory body, the Convention has empowered itself by means of its ambitious constitutional objective. The review of the procedures for substantiating composition reveals thin grounds for claiming legitimacy of representatives for such a move. Acting de facto the Convention seems to place the burden of legitimacy on its ability to produce a successful outcome. This may bind European Council members, but the legitimacy of such move will have to pass the test of citizens' consent, and this will mark whether the ambiguous nature of the Convention suited the constitutional objective.

\subsection{Agenda}

The perception of failure at the Nice IGC derived, in parallel with the style of negotiations, from the kind of issues dealt with. Observers and politicians agreed that the mere distribution of votes does not suffice for mobilizing public opinion nor even for resolving the problems of an expanding Union. They also perceived that the permanent strategic negotiation of packages of specific (and even very specific) items through traditional bargaining, pay-offs and log-rolling would risk turning the engagement into a quasi permanent revision process.

This may explain a switch towards a more deductive strategy that takes an overall definition of the Union as its point of departure. Reform, in words of Hoffman and VergesBausili, aims at settling "ontological" questions for the time being. ${ }^{93}$ The Declaration of Nice anticipated four central issues (drawing from the recurrent themes in the declarations and speeches of European leaders) and the mandate for the Convention restated these, asking it 'to consider key issues arising for the Union's future development and try to identify the various possible responses'. The lack of juridical efficacy of the Declaration may explain its relatively audacious wording ${ }^{94}$ although, far from leaving the Convention with the whole task of identification, the European Council specified four main issues to guide this reflection in the Declaration of Laeken:

- Division and definition of competences in the EU

- Simplification of the Union's instruments

- More democracy, transparency and efficiency in the EU

- Simplification and reorganization of the Treaties

Additionally, 56 questions (whose selection and wording reveals certain biases) developed these issues. In any case, the Laeken Declaration is a remarkable achievement, ${ }^{95}$ since it opened up the exercise of defining the Union ${ }^{96}$ (although if it is measured against the original ambition of providing a global vision of the ultimate goal of European unification, the declaration is far from being a success). ${ }^{97}$ The only limitation so far seems to be a pragmatic approach. The Spanish Presidency exhorted the members of the Convention to stick to the issues raised by the Declaration of Laeken. Literally, the Presidency recommends that abstract theoretical debates taken up with the definition of artificial archetypes must be avoided, and 
the need to meet citizens' concerns must constantly be borne in mind. Giscard took this philosophy a step further and postponed the discussion of the institutional design on the basis of the well-known functionalist principle that "task should define the institutions and not vice versa".

The agenda of the Convention poses huge difficulties due to the heterogeneity of issues and solutions required. The first convention benefited from a clear mandate (identification and codification) and a defined range of issues (i.e. fundamental rights). In contrast, the current Convention has to deal (again) with the Charter of Fundamental rights on which the essential issue (once solemnly proclaimed) is a political decision as to its legal and juridical position. Then, the largely shared objective of simplification involves a process of identification and codification that replicates the exercise of the first convention. Since this is not merely a technical exercise, it could of itself be the sole object of a Convention. Next, some specific policies, such as third pillar issues and security and defence, require a previous task of definition. Progress in these areas seems to be dictated more by Member States requirements than by "constitutional design" and, hence, definitive settlements seem unlikely. Another issue, distribution of competences, has a transversal reach. Given the dialectic character of the exercise of competence within composite political structures, the definitive and clear settlement sought also seems unlikely. In short, the prospects for closing the process within a single document are questionable.

\subsection{Status of the outcome of the Convention.}

The mandate of the European Council asked the Convention to produce a final document that could adopt two different forms. Firstly, it could adopt the form of a number of possible options on the various questions examined with an indication of the degree of support for each of these. Secondly, the Convention could draft a list of recommendations in case of consensus. As it has been argued, the preference for the production of a consensual text that could guarantee the success of the next IGC emerged quickly within the

Convention. ${ }^{98}$ Of course, the IGC is not bound by the results of the Convention. The Declaration of Laeken defined the status of the document produced as the starting point for the debates in the IGC together with national debates. This represents an improvement from earlier processes of preparation of IGCs (for instance, the reflection group created for the 1996 IGC), since the Convention embodies a more open, transparent and legitimate stocktaking exercise. And it is also an improvement on the former convention on the Charter, which did not have a mandate to prepare an IGC. However, the outcome from the Convention will not have a mandatory character for the IGC. Political reasons militate against, since national governments obviously do not want to relinquish full control over the result and an IGC guarantees at least a veto on any unwanted outcome, as well as offering the additional attraction of an arena for bargaining. From a strictly juridical point of view, the EU has limited room for a transformation of the constitutional procedure without a formal amendment of the rules guiding it (Art. 48 TEU).${ }^{99}$ However, it is obvious that the legitimacy deriving from the democratic credentials (however limited) of the body and procedure followed will sharply reduce largely national governments' room for manoeuvre should a strong consensus on a precise text be achieved.

The second broadly shared agreement refers to the precise form of the consensual document. The Declaration of Laeken contemplates the long-run possibility of adopting a 
Constitution, and this (together with the large number of declarations by European leaders) acted as a reference point for the Convention which, nevertheless, did not have a constitutive mandate. Moreover, some national governments warned that even though the Union could endeavour towards a Constitution in future, the Convention should product options and/or recommendations since it does not have the legitimacy required to transform itself into a constituent assembly, and modification of the Treaties is reserved for an IGC. ${ }^{100}$ The Convention has moved pragmatically to a lower level. It has generated, in constructivist fashion, a discourse that may allow the outcome to be shaped under the Laeken mandate, but in a manner that is also close to the constitution model. In his opening speech, Giscard called for a broad consensus on a single text that may open the door to a European Constitution. He proposed calling this a 'constitutional treaty' in order to avoid semantic disputes. ${ }^{101}$ Quite early in the debate, a majority of the Presidium declared that the Convention objective should be to draft a "constitutional treaty for Europe" and some Convention members endorsed this goal in plenary sessions. ${ }^{102}$ Giscard himself has repeated the view that conventioneers are conscious that the Convention should propose the future Constitution of Europe (or constitutional treaty). ${ }^{103}$ In July 2002, 18 members and alternates submitted a Motion for the preparation of a Constitutional Treaty that asked the Commission to prepare a text to be discussed in the October plenary session using the EUI document and the Convention debates. ${ }^{104}$ In reality, this seemed to anticipate actual developments: in June 2002, certain media aired a draft Non Paper for a 'Foundational Treaty' 105 and finally the Presidium tabled a proposal ${ }^{106}$ at the end of October which was preceded and followed by several other drafts. ${ }^{107}$

\section{Concluding remarks}

This paper has assumed that constitutional politics (the creation and transformation of fundamental and foundational rules) have become more democratic within the EU.

Objectively, the Convention represents the most open and representative debate on the reform of the EU in its whole history. Success, though, will be determined by its ability to produce a consensual document that presents clear options for the 2004 IGC. Success, also, will be determined by perceptions of the legitimacy of this outcome. Whilst it is too early yet to evaluate these two issues globally, this paper discusses some of the procedural shortcomings that the Convention presents if it is to embody a legitimate and democratic deliberative process. By themselves, these do not nullify the validity of the possible outcome, although some concerns about its legitimacy may be raised. In short, the convention enhances the representativeness of the participants in the preparation phase, as well as marginally improving their accountability. The selection procedure might raise questions as to the legitimacy of these representatives but these would only be significant depending on the final status of the Convention. Clearly, a document that merely serves as basic reference for the IGC will not need to pass such a stringent test. As for the procedures framing deliberation, participants enjoy a certain degree of autonomy, which is essential for deliberation without, on the other hand, relinquishing their links with their original institutions. Probably, the most significant organisational weakness of the Convention is the pre-eminent position of its steering organs, President and Presidium, which have a significant capacity to bias debates and even final results. Although the method of consensus adds marginally to the deliberative capability of the convention, it seems a priori to reinforce this trend. And, so far, there is 
certain incommensurability between the procedure followed (debate) and the objective declared (a constitutional treaty).

In any case, whilst conventioneers, politicians and academics alike focus their attention preferentially on the possible outcome of the Convention, another complementary and unavoidable debate seems to go unnoticed: what are the links between the Convention and its outcome and the two following phases of decision and ratification. Democratic legitimacy constrained at the preparatory stage will not resolve past difficulties of EU constitutional politics. However good the outcome of the Convention may be in deliberative terms and/or constitutional standards, it must endure the test of accountability to and scrutiny by the citizens. 


\section{Notes}

${ }^{1}$ A draft of this paper was presented at the 1st Pan-European Conference on European Union Politics, Bordeaux, 26-28 September 2002. I am grateful to the participants for comments and suggestions. Antje Wiener and Jo Shaw also made valuable comments and suggestions that have greatly improved it. Of course, responsibility for any errors is mine alone.

${ }^{2}$ An exception is Jo Shaw Process, responsibility and inclusion in EU constitutionalism: the challenge for the Convention on the Future of the Union The Federal Trust for Education and Research Working Paper September 2002 www.fedtrust.co.uk/EU constitution

${ }^{3}$ Hoffmann, L and Verges-Bausili, A. (2003) The reform of Treaty revision procedures: The Convention on the Future of Europe, in Börzel, T. and Cichowski, R. (eds.) The state of the European Union VI: Law, Politics and Society (Oxford, OUP, forthcoming)

${ }^{4}$ Aldecoa Luzárraga, F. Primeros resultados del debate sobre el futuro de Europa: entre la profundización y la refundación (2000-20001) Documento de Trabajo del Real Instituto Elcano de Estudios Internacionales y

Estratégicos http://www.realinstitutoelcano.org/documentos

${ }^{5}$ Magnette, P. Deliberation vs. negotiation A First Analysis of the Convention on the Future of the Union Paper prepared for the First Pan-European Conference of the ECPR Standing Group on the European Union Bordeaux, 26-28 September 2002

${ }^{6}$ Hoffmann, L. The Convention on the Future of Europe - Thoughts on the Convention-Model Jean Monnet Working Paper 11/02 http://www.jeanmonnetprogram.org/papers/papers02.html

${ }^{7}$ Shaw, J. cit. op. cit. pag. 13

${ }^{8}$ Joerges, C. and Neyer, J. (1997), "From Intergovernmental Bargaining to Deliberative Political Processes: The Constitutionalisation of Comitology", European Law Journal, 3/2: 273-99 and Joerges, C. (2001), "In Defense of Deliberative Supranationalism", European Integration Online Papers, 5/4.

${ }^{9}$ Eriksen, E. O. and Fossum, J. E. (2002) Democracy through strong publics in the European Union? Journal of Common Market Studies 40:3 pages 401-424 at 403

${ }^{10}$ Hoffmann, L. op. cit.

${ }^{11}$ Dinan, D. (2002) Institutions and governance 2001-2002: Debating the EU's future Journal of Common Market Studies 40 Annual Review pages 29-43. The Irish referendum and anti-globalisation demonstrations both in Göteborg and at the G-7 meeting in Genoa reinforced the perception of rejection and aloofness from large sections of public opinion. In his speech at the inaugural session of the Convention the President of the Council, Aznar, recognized explicitly that Nice is the reason for which we are here. Speech to the opening session, 28 February 2002, Brussels; 05/03/2002; CONV 4/02.

${ }^{12}$ Deloche-Gaudez, F. (2001) The Convention on a Charter of Fundamental Rights: a method for the future? Groupement d'Etudes et de Recherches Notre Europe Research and Policy Paper No. 15

${ }^{13}$ In this line, de Schutter writes that the general impression was that the drafting process of the Charter compared favourably with the classical intergovernmental negotiations that preceded EU constitutional changes, even when such intergovernmental conferences were prepared by 'reflection groups'. De Schutter, O. (2002) Europe in search of its civil society, in Eriksen, E.O.; Fossum, J. E. and Menéndez, A. (eds.) The Chartering of Europe, The Charter of Fundamental Rights in context ARENA Report 8/2001 pages.155-181

${ }^{14}$ Speech of the Prime Minister of Finland, Mr. Paavo Lipponen at the European University Institute, Florence 9th April $2001 \mathrm{http}: / /$ valtioneuvosto.fi/liston/base.lsp?r=5300\&k=en\&old $=1300$

${ }^{15}$ Benelux Memorandum on the Future of Europe, 26 June 2001 http://europa.eu.int/futurum/documents/other/oth200601 en.htm

${ }^{16}$ See on this Ludlow, P. (2002) The Laeken Council EuroComment (European Council Commentary ) Vol. 1 Num. 1 Brussels

${ }^{17}$ The Assizes approved a Declaration calling for a Constitution (Bull. EC 11-1990 point 1.1.1 page 10). See also the EP Resolution of 12 July 1990 on the preparation of the meeting with national parliaments to discuss the future of the Union (the Assizes). Second Interim Report (Duverger Report) Doc. A 3-162/90 22.6.90

${ }^{18}$ Ludlow, P. op. cit. 55-69; Magnette, op.cit.

${ }^{19}$ Magnette, P. op. cit.

${ }^{20}$ Resolution on the Amsterdam Treaty OJ C 371 8.12.1997

${ }^{21}$ Resolution on the Constitutionalization of the Treaties, 25 October 2000 (A 5-0289/2000) 
${ }^{22}$ Resolution on the Treaty of Nice and the future of the European Union A 5-0168/2001

${ }^{23}$ Resolution on the constitutional process and the future of the Union (2001/2180(INI)) Doc. A5-0368/2001

${ }^{24} \mathrm{See}$, for instance, the speech by Vitorino, A. 'The Convention as a model for European constitutionalisation' http://www.europa.eu.int/futurum/documents/speech/sp140601 en.htm

${ }^{25}$ Sustein, C. Constitutions and democracies. An epilogue, in Elster, J. and Slagstad, R. (eds.) Constitutionalism and democracy (Cambridge: CUP, 1988) pages 327-356

${ }^{26}$ The Committee of Regions drew up the Liege Declaration that called for the involvement of all sub-national political levels, particularly the Regions with legislative powers whenever the topic of division of competences is discussed. Liege Declaration of November 2001, Resolution on strengthening the role of regions with legislative power in the European Union. Second Conference of the Presidents of Regions with legislative power http://europa.eu.int/futurum/conoth_en.htm\#po

${ }^{27}$ Deloche-Gaudez, F. op. cit.

${ }^{28}$ This provoked some tense situations: the designation of G. Fini (a neofascist of Alianza Nazionale) as representative of the Italian Prime Minister raised criticism among EU governments and politicians. It is also noteworthy that no delegates the first Convention repeated.

${ }^{29}$ The logic for selecting two national MPs was to have one from each chamber.

${ }^{30}$ Delouche-Gaudez, F. op. cit. pag. 12; Shaw, J. op. cit.

${ }^{31}$ This was apparent in the first convention: MEPs knew each other and they were used to work together and submitting to a degree of parliamentary discipline. Delouche-Gaudez, F. op. cit. pag. 11

${ }^{32}$ Vitorino, A. Interview Revue du Marché commun et l'Union européenne num. 458 pag. 285 mai 2002

${ }^{33}$ It would be difficult to agree with Philippart that the Presidium is "dominated by EU institutions" though. Philippart, E. (2002) The "European Convention": Anatomy of the new approach to constitution-making in the EU EUSA Review 15:2 pags. 5-7

${ }^{34}$ Delouche-Gaudez, F. op. cit.

${ }^{35}$ Note on the inaugural meeting 28 February 2002, Brussels; 11/03/2002; CONV 7/02. Requests by the candidate countries; $14 / 03 / 2002$; CONV 10/02.

${ }^{36}$ The socialists presented the following two submissions: The European project of the socialist: the new federalism (CONV 63/02) and Proposals of the European socialist (CONV 182/02). During the summer (30 and 31 August) the socialists held a meeting in Birmingham that resulted in the manifesto Priorities for Europe, 3 October $2002 \mathrm{http}: / /$ europa.u.int/futurum. The PPE also presented its proposal A constitution for Europe CONV 325/02. Finally, the proposal of A. Duff, A model of Constitution for a federal union of Europe, CONV 234/02 can be regarded as the contribution of the Democrats and Reformists.

${ }^{37}$ Interview with Wolfgang Schäuble, El Pais, 5 September 2002

${ }^{38}$ Giscard d'Estaing, V. (2002) La dernière chance de l'Europe unie, Le Monde, 22.07.2002.

${ }^{39}$ Shaw, J. op. cit. pag. 18

${ }^{40}$ Magnette, P. op. cit.

${ }^{41}$ In contrast, Magnette argues that the three main shaping rules are informal: the 'as if' rule (i.e. acting as if the results of the Convention was to draft a constitution), the rule of consensus in decision-making and the 'Convention spirit'. These three elements and their shortcomings are discussed throughout this paper.

${ }^{42}$ Hoffmann, L. op. cit.

${ }^{43}$ Magnette, P. op. cit.

${ }^{44}$ Deloche-Gaudez, F. Op. Cit. pag. 36

${ }^{45}$ Giscard, La dernière, cit. The British weekly The Economist used the same expression.

${ }^{46}$ More Europe Program of the Spanish Presidency of the EU 1-1/30-6-2002 http://www.ue2002.es/principal.asp?opcion=3\&subopcion=1\&idioma=ingles

${ }^{47}$ On the experience of the first convention, Deloche-Gaudez writes that there were no mandatory obligations for them to follow, op. cit. pag. 15.

${ }^{48}$ The Spanish case illustrates this point: Aznar appointed an MEP and convinced Europeanist, Ana de Palacio, as his personal representative. She underlined that she understands the Convention the same way Aznar understands it. Interview, El País 2 February 2002. Later, she responded in an internet forum that she did not have mandatory instructions. She conceded though, that Aznar transmitted to her the defence of his ideas on the space of security, freedom and justice, the maintenance of the acquis communautaire, the completion of the single market and the need to raise the Union's profile in the world. Ana de Palacio (MEP, Representative of the Spanish government in the Convention of the Future of the Union and Member of the Presidium. Interview for 
El País Digital, 13-03-2002. Later, in July 2002, she became Foreign Affairs Minister, and she has remained as a Convention and Presidium member.

${ }^{49}$ See Verbatim Report http://www.europarl.eu.int/europe2004/textes/verbatim 020624.htm

${ }^{50}$ Crum, B. Laying building blocks or just window dressing?-The first half year of the Convention on the future of the EU http://www.ceps.be/Commentary/Jul02/crum.php

${ }^{51}$ Shaw, J. op. cit. pag. 25

${ }^{52}$ For instance, the contribution of the French Senat CONV 12/02 or the Bundesrat Resolution Having Regard to the Themes of the Convention on the Future of the European Union 586/02 (Decision)

${ }^{53}$ Even though Amato looked as the most likely candidate, political pressure from the French President, Chirac, decided the election of Giscard d'Estaing as President. According to Magnette, Jospin pretended not to understand Delors' wish to be nominated. France secured the support of Germany and Austria before the Laeken summit. The smaller countries were not enthusiastic about Giscard and expected that Antonio Guterres, Wim Kok or Giuliano Amato would be candidates although they failed to prepare a real alternative. Amato obtained one of the two Vice-Presidencies as compensation, and Jean-Luc Dehane the other. Giscard did not benefit from certain press rumours that presented him as "greedy". Allegedly, he asked for the same salary as the President of the Commission plus two offices in Paris and Brussels, permanent staff in both and travel infrastructure. On the events surrounding the nomination of the President, see Ludlow, P. op. cit. pages. 68-70

${ }^{54}$ Hoffmann, L. and Verges-Bausili, A. op. cit.

${ }^{55}$ Giscard, La dernière, cit. See also his speech at the College of Bruges, cit. note 65

${ }^{56}$ Hughes, K. The Future of Europe Convention: travelling hopefully? Joint Working Paper EPIN (European Policy Institutes Network) and CEPS (Centre for European Policy Studies, Brussels) http://www.epin.org/papers/01 Hughes Convention.doc

${ }_{58}^{57}$ Note on the plenary meeting - Brussels, 6 and 7 June 2002;19/06/2002; CONV 97/02 at page 4

${ }^{58}$ Ibidem page 7

${ }^{59}$ Idem

${ }^{60}$ Idem page 10

${ }^{61}$ Intervention of the President of the European Council, J. M. Aznar at the opening meeting of the Convention on the Future of the European Union Brussels, 28/02/2002. CONV 4/02 page 4.

${ }^{62}$ Note on the plenary session Brussels, 24 and 25 June 2002, 04/07/2002, CONV 167/02

${ }^{63}$ See the Verbatim Report of the session http://www.europarl.eu.int/europe2004/textes/verbatim 020624.htm

${ }^{64}$ See note 38

${ }^{65}$ Intervention de Valery Giscard d'Estaing. Rentrée académique du Collège d'Europe. Bruges, 2 October 2002. www.euobserver.com

${ }^{66}$ Giscard also criticized Prodi's draft constitution with undisguised contempt.

${ }^{67}$ In an interview in Le Monde on 10 January, he compares himself with the chairman of the Philadelphia convention, George Washington.

${ }^{68}$ The Presidium consists of the Convention Chairman and Vice-Chairmen and nine members drawn from the Convention comprising the representatives of all the governments holding the Presidency of the Union during the Convention (Spain, Denmark and Greece), two national parliament representatives, two European Parliament representatives and two Commission representatives. The Presidium invited one member of the Convention designated by the representatives of the candidate countries to all its meetings.

${ }^{69}$ Hughes, K. op. cit. According to some sources, the Praesidium members put quite a lot of pressure on Giscard with regard to the working methods for the final phase of the convention.

${ }^{70}$ Note on the plenary meeting - Brussels, 6 and 7 June 2002, 19/06/2002 CONV 97/02

${ }^{71}$ Note on the plenary meeting - Brussels, 23 and 24 May 2002 29/05/2002 CONV 60/02

${ }^{72}$ Note on the working methods; 14 March 2002; CONV 9/02 Brussels,. Revision of CONV 3/02. In contrast, the first convention did not adopt rules of procedure, a fact that sometimes rendered decision-making more opaque. D-G, 23. Philippart mentions that some 300 amendments to the original rules were tabled. Magnette gives the precise figure of 347 .

${ }_{73}^{73}$ Ludlow, P. op. cit. pag. 60

${ }^{74}$ Note on the plenary meeting - Brussels, 23 and 24 May 2002; 29/05/2002; CONV 60/02

${ }^{75}$ Requests by the candidate countries; 14/03/2002; CONV 10/02

${ }^{76}$ Interpretation from the languages of Applicant Countries; 28/03/2002; CONV 18/02

${ }^{77}$ Delouche-Gaudez, F. pag. 18

${ }^{78}$ I am grateful to Emanuela Lombardo for figures and information on the Forum. 
${ }^{79}$ Scott, J. (2002) The culture of constitution making? "Listening" at the Convention on the Future of Europe German Law Journal 3:9 http://www.germanlawjournal.com

${ }^{80}$ Scott, J. (2002) "Listening" to Europe: Progress report on the European Convention EUSA Review 15:4 pages 4-6

${ }^{81}$ Follow-up to inaugural session of Convention; 08/03/2002; CONV 8/02, Annex II

${ }^{82}$ Shaw, J. op. cit. pag. 25

${ }^{83}$ Delouche-Gaudez, F. op. cit. page 23

${ }^{84}$ Scott, J. op. cit.

${ }^{85}$ Delouche-Gaudez, F. op. cit. page 25

${ }^{86}$ Hoffmann, L and Verges-Bausili, A. op. cit.

${ }^{87}$ Time limits started at the session on 6-7 June 20002 CONV 97/02

${ }^{88}$ Delouche-Gaudez, op. cit. page 37

${ }^{89}$ Description of the current system for the delimitation of competence between the European Union and the Member States 28/03/2002 CONV 17/02

${ }^{90}$ The summary identifies a "broad trend on the need to avoid calling into question the present remit of the Union with only two members wishing certain competencies given back to Member States" CONV 40/02

${ }^{91}$ Delimitation of competence between the European Union and the Member States - Existing system, problems and avenues to be explored 15/05/2002 CONV 47/02

${ }^{92}$ See note 71 above

${ }^{93}$ Hoffmann, L. and Verges-Bausili, A. op. cit. They concede that the Convention has realised that certain policy areas required deeper attention.

${ }^{94}$ Aldecoa Luzárraga, F. op. cit.

${ }^{95}$ Dinan, D. op. cit. page 35

${ }^{96}$ This open character of the Laeken Declaration owes much to the tactical struggle among national governments. Thus, the French and British delegations insisted that the diagnosis of the Union should be less pessimistic. They also wanted the suppression of a sentence mentioning the 'deadlocks of unanimity'. In their opinion, the question on the direct election of the President of the Commission should be re-formulated since they thought that the initial one prompted a positive answer. Finally, they requested some other questions concerning the strengthening of the Council and the re-nationalisation of certain policies. See Magnette, op. cit. ${ }^{97}$ Ludlow, P. op. cit. pag. 73

${ }^{98}$ Note on the plenary meeting - Brussels, 21 and 22 March 2002; 25/03/2002; CONV 14/02. From a scholarly standpoint, Jo Shaw argues that effectiveness of the Convention depends upon its ability to find a set of compromises which can be carried by a sufficiently "large consensus" of its members to ensure that it can produce a single set of outputs. Shaw, J. op. cit. pag. 25

${ }^{99}$ Rodrigues, S. (2001) La réforme de l'Union Européenne: changement de méthode? À propos du débat sur l'avenir de l'Europe au Conseil Européenn de Gand Revue du Marché común et de l'Union européenne no. 452 pag. 590. The ECJ case-law established that a modification of the Treaties can only result from a revision in accordance with article 236 CEE (current 48 TEU). CJCE 8.4.76 Mlle Defrenne n. 43/75 Rec. 455

${ }^{100}$ Moscovici, P Interview Revue du Marché commun et l'Union européenne num. 456 pag. 145 mars 2002

${ }^{101}$ Giscard,V. Speech at the opening session of the Convention 28 February 2002 Conv 04/02

${ }^{102}$ Note on the plenary meeting - Brussels, 21 and 22 March 2002; 25/03/2002; CONV 14/02

${ }^{103}$ Giscard, V. La dernière, cit. See also the Verbatim report, cit.

${ }^{104}$ Motion for a decision on the preparation of a Constitutional Treaty; 10/07/2002; CONV 181/02

${ }^{105}$ Apparently, Amato drafted the Non Paper, which contained 10 loosely defined parts. See www.Euobserver.com

${ }^{106}$ Preliminary draft Constitutional Treaty CONV 369/02 Brussels, 28 October 2002

${ }^{107}$ Among many others, in December 2002 the Commission submitted its long Contribution to a preliminary draft Constitution of the European Union Brussels, 05/12/2002. MEPs Andrew Duff and Jo Leinen also submitted drafts. 